\title{
ADOLFO COUVE: EL DESCABEZADO
}

\author{
Leonidas Morales T. \\ Universidad de Chile, Santiago de Chile, Chile \\ lmoralest@vtr.net
}

\section{RESUMEN / ABSTRACT}

Este artículo se centra en las dos últimas novelas de Adolfo Couve, La comedia del arte (1996) y Cuando pienso en mi falta de cabeza (La segunda comedia), esta última de publicación póstuma (2000). El artículo se propone una lectura alegórica de la conversión en estatua de cera del pintor Camondo, protagonista de ambos relatos, y a continuación de la pérdida de su cabeza. La hipótesis sostiene que la pérdida de la cabeza alegoriza un tiempo cotidiano, el del mundo de Couve, que gira y se repite a sí mismo, cerrado, sin horizonte, es decir, un tiempo "descabezado" (sin "futuro"). Desde esta hipótesis se hace posible construir el sentido coherente de una serie de formas narrativas (que incluyen lenguaje, espacio, tiempo, personajes) y que en su conjunto dan cuenta del modo particular en que la narrativa de Couve se arma y se desarrolla.

PALABRAS ClaVE: tiempo, repetición, alegoría, forma narrativa.

\section{Adolfo Couve: The “BeHEADED”}

This article focuses on the last two novels by Adolfo Couve, La comedia del arte (1996) and Cuando pienso en mi falta de cabeza (La segunda comedia), posthumously published in 2000. The article proposes an allegorical reading of the transformation of the painter Camondo into a wax statue, the protagonist of both novels who later loses his mind. The article argues that the loss of the mind allegorizes a quotidian time, in tune with Couve's world, which spins and repeats itself, closed, without a horizon, a "beheaded" time (lacking future). This allows the possibility to build a coherent sense of a series of narrative forms (which include language, space, time, characters) and that, taken as a whole, show the particular way in which Couve's narrative is built and developed.

KEYWORDS: Time, repetition, allegory, narrative form. 
Sabemos que Adolfo Couve (1944-1988), además de narrador fue al mismo tiempo un pintor reconocido, original e intenso como en sus relatos. En él narrativa y pintura, ambas surgidas y desarrolladas, como él mismo lo ha dicho, al margen de tendencias, dominantes o no (Couve 2003), mantienen entre sí una íntima correspondencia y un diálogo de tonos e imágenes primordiales, confirmando así, para quien lo ha leído y ha visto sus cuadros, que ambas parecen levantarse desde las mismas grietas, vacíos o ausencias de un sujeto biográfico.

En 1995, tres años antes de morir, Couve publicó la novela La comedia del arte. En su archivo quedaron los manuscritos de otra novela, publicada finalmente en 2002 con el título de Cuando pienso en mi falta de cabeza (La segunda comedia). Su subtítulo entre paréntesis le advierte al lector de algo que para éste será por lo demás manifiesto: que ambas novelas forman un todo, de continuidad narrativa y de sentido. Y así las leeremos aquí. Podríamos subrayar esta continuidad diciendo que estamos frente a una sola novela publicada en dos partes.

En una sucesión de novelas de un mismo narrador, la condición de "última" nunca puede ser irrelevante, el mero suceder de un fin. Por lo pronto, esa condición de última siempre nos obligará a preguntarnos por el "lugar" que esa novela ocupa (desde el punto de vista de su forma, visión y jerarquía estética) dentro del conjunto de novelas del autor. Las respuestas a esa pregunta son desde luego muy diversas. Pero, en general, el lugar que ocupan no representa un lugar que claramente desborde las expectativas creadas por las novelas anteriores. En Couve, ese desborde se produce, y también claramente. Más aún, las expectativa en este caso operan justamente al revés: de las dos últimas novelas de Couve, de la forma de la historia narrada, se desprende un sentido que tiene consecuencias iluminadoras sobre el resto de la obra narrativa del autor.

En efecto, La comedia del arte y Cuando pienso en mi falta de cabeza, dentro del todo unitario que constituyen, no solo se dejan leer sino que exigen ser leídas desde la sorprendente figura simbólica que adopta en ellas el protagonista de la historia, el pintor Camondo: la de un cuerpo convertido primero en estatua de cera y luego descabezado. Lo que me propongo hacer aquí es construir la lógica (el sentido) de la metamorfosis del pintor descabezado y de sus peripecias, para desde ella, desde las claves que aporta, hacer evidente otra lógica más amplia: aquella a la que responde la 
forma interior de cada uno de los relatos de Couve desde que comienza su publicación en la década de 1960.

Las narraciones de Couve publicadas suman en total 15, incluyendo en ellas las dos compilaciones póstumas, ambas con la palabra "completa" en sus títulos: una del 2003, Narrativa completa, y la otra del 2013, Obras completas. Sin embargo, para el desarrollo y fundamentación de mi propuesta solo me serán indispensables unas pocas narraciones. Mi corpus incluye, además de las dos novelas últimas, las cuatro reunidas en el libro El cuarteto de la infancia (Couve 1996): El picadero (1974), El tren de cuerda (1976), La lección de pintura (1979) y El pasaje (1989).

Al margen de que continúe siendo un autor de lecturas más bien minoritarias, la crítica literaria no ha podido pasar por alto una obra narrativa como la de Couve. En su recepción es dominante la crítica literaria periodística, que no suele escapar a algunas limitaciones. La principal: la tendencia al "reduccionismo", es decir, a simplificar las problemáticas mediante su reducción a temas más o menos "instalados" en los medios. En el caso de Couve, por ejemplo: el tema de la infancia, su condición de pintor-escritor, la "perfección" de su prosa, su repliegue (en una suerte de exilio voluntario) en la ciudad de Cartagena, y, desde luego, su suicidio. Hay sin duda crónicas y entrevistas que se liberan de esta dominante. Pienso en un cronista como César Aira y en las dos entrevistas publicadas póstumamente, la de Claudia Donoso y la de Cristián Warnken. Por su parte, la crítica académica es escasa. Dentro de lo que hay, son inevitables los prólogos de Adriana Valdés a diversas novelas y compilaciones, y, de modo principal, el ensayo de Fernando Pérez Villalón, "Escenas de Adolfo Couve (estudio en cinco miradas)"

En cualquier caso, ni en la crítica periodística ni en la académica encontramos un examen de las conexiones de sentido entre su producción anterior y la figura singular en que se encripta la significación profunda de sus dos últimas novelas, es decir la figura del descabezado. Por lo pronto, debo reconstruir los detalles principales de su historia. Ésta transcurre en Cartagena y comienza

Los textos a los que me refiero formarán parte de la bibliografía de otro ensayo mío sobre Couve por publicar. 
justamente en la novela La comedia del arte. Es la historia de un pintor, Camondo, y de su modelo, Marieta. Ambos personajes se nos aparecen ya envejecidos. En una suerte de imagen en el espejo, han llegado a una pensión de Cartagena, la San Julián, administrada por dos hermanas viejas, lugar donde vive asimismo un grupo de mujeres también viejas, antiguas sirvientas cuyos patrones han venido a dejarlas ahí como a una "casa de acogida". Estas viejas, y el estado del lugar que habitan, son evidentemente "donosianos": han salido de la novela de José Donoso El obsceno pájaro de la noche, es decir, del modelo representado por la Casa de Ejercicios, casa vieja y derruida como sus habitantes, antiguas sirvientas, ahora inútiles, llevadas igualmente por sus patrones a esperar en ella su fin.

Ninguno de los dos, ni el pintor ni su modelo, se resignan a su presente. En un juego referencial con la historia de la pintura y la inflexión que introduce en ella la aparición de la fotografía, la modelo le pone los cuernos al pintor justamente con un fotógrafo de playa, Aosta. Para Camondo, una doble "traición": a él y, en él, al arte de la pintura. Pero este pintor busca a su vez cómo enfrentar su inquietante presente que es el de su oficio. Lo medita en largas y repetidas caminatas. Finalmente, se resuelve y arma en la playa una escena a la manera de un ritual pagano, paródico desde luego: reúne en el lugar elegido su caballete, su caja de pinturas, el piso plegable y la sombrilla. Se venda los ojos con su propia corbata, levanta los brazos e interpela al dios Apolo, "abjurando" de los talentos artísticos de él recibidos, y haciéndole entrega, en ese acto, de los instrumentos de su oficio, devolviéndoselos porque siente que ha fracasado, que no ha estado a su altura, o que ellos no han estado a la suya. Un viejo vago que pasaba por ahí, apodado el Conejo, creyó que alguien había dejado u olvidado esos útiles de pintor, y se los lleva. Cuando Camondo se quita la venda y ve que no están, asume que Apolo lo ha escuchado y los ha recibido.

La escena anterior introduce una dimensión fantástica-paródica que no desaparecerá en adelante. En efecto, la novela continúa con la venganza de Apolo al desaire sufrido. Llama a la musa del pintor, ahora "desocupada", y le ordena que vaya a ejecutarla. Ella baja del Olimpo, se disfraza de "mujer barbuda" (personaje ambiguo, común en los circos pero también presente en la pintura: Zurbarán) y consigue de manera astuta llevar a Camondo hasta la torre donde había vivido en la San Julián, casa ahora abandonada. Lo hace beber un brebaje preparado por ella y, como efecto del mismo, sufre una metamorfosis: se convierte en una estatua de cera. Se consumaba así la primera parte de la venganza de Apolo. 
Marieta, que ha estado esperando al pintor durante dos días, se desespera. Entonces se presenta de nuevo la mujer barbuda y también consigue que Marieta la acompañe. Cuando comienza a resistirse, le presenta una foto de carnet de Camondo y Marieta obedece. Por una entrada secundaria, para que ella no se de cuenta, y poniéndole además en la cabeza una bolsa de plástico, la conduce hasta la San Julián. Entran y suben a la parte alta. Allí la mujer barbuda le saca la bolsa de plástico y deja a Marieta frente a la estatua de Camondo. Tan realistamente estaba hecha que Marieta se arrojó a sus brazos, golpeándolo contra el muro. Asombro, perplejidad fue su reacción. Sin saber qué hacer, decidió quitarle la cabeza e irse con ella (con él metónicamente). Así lo hizo (cuando la mujer barbuda había ya desaparecido).

Tomó un taxi. El avance del vehículo mientras ella iba con la cabeza del pintor sobre sus piernas representaba un extraño funeral. Este "funeral" sin embargo tiene antecedentes en la literatura. Si la pensión San Julián remitía a Donoso y a la Casa de Ejercicios, detrás de esta escena de Marieta y la cabeza de Camondo avanzando en un taxis, también reconocemos un referente, una suerte de modelo parodiado. Ahora se trata de Stendhal y de su novela Rojo y negro. Sin duda, en esta escena Couve parodia la escena también final de Rojo y negro, la novela de Stendhal: después del juicio que lo condena, Julien Sorel es guillotinado y su amante, Matilde, asiste al entierro sentada en un coche cubierto de luto y llevando también, como Marieta, sobre sus piernas la cabeza del cuerpo de Sorel. La escena es ésta: "Matilde siguió a su amante hasta la tumba que él eligiera. Gran número de sacerdotes escoltaban el ataúd $\mathrm{y}$, sin que nadie lo supiera, sola en su coche enlutado, ella llevaba sobre sus rodillas la cabeza del hombre a quien tanto había amado" (Stendhal 675).

Así es como se introduce en La comedia del arte la figura del descabezado. La novela póstuma, Cuando pienso en mi falta de cabeza (La segunda comedia), presupone esta figura desde el título mismo. Y más, la novela se abre con un hecho que el lector nunca podría habérselo imaginado: que Camondo (es decir, su estatua descabezada) sigue "vivo". Lo que la novela comienza narrando son justamente las primeras reacciones y pensamientos de Camondo descabezado, después de abandonar la torre de la San Julián. En mi hipótesis de lectura de la obra de Couve, el descabezado deja a la vista exactamente las claves de su comprensión. 
Una breve referencia histórica es aquí necesaria. La sociedad moderna, capitalista o burguesa, desde sus orígenes y su consagración con la Revolución francesa, junto con "racionalizar" el trabajo, la producción económica y, en general, la vida cotidiana (Max Weber), introduce una nueva concepción del tiempo y un nuevo concepto de historia dominantes. Un concepto fundado en la linealidad del tiempo. Esta linealidad, a su vez, sostiene y hace posible un conjunto de nociones correlativas: lo "nuevo", el "progreso" y el "futuro" (Paul Ricoeur 399-411)2. En las últimas décadas del siglo XIX y primeras del XX el "progreso" del capital alcanza niveles tales que la alta burguesía, enriquecida, vive una suerte de epifanía como clase social (mientras los que hacen posible esa riqueza, la clase de los trabajadores, viven sus peores miserias $^{3}$ ). Su euforia la traduce en un estilo de vida paralelo de gran refinamiento, ostentoso, que define un período histórico al que nos referimos con la frase la "belle époque", es decir, la "bella época" de la burguesía.

La Primera Guerra Mundial pone fin a la euforia y la hunde en medio de la agitación vanguardista en el arte y revolucionaria en lo social, ambas tras una misma utopía antiburguesa y anticapitalista. En las vanguardias, el sueño de una sociedad donde fuera posible una relación de inclusión e implicación recíproca entre arte y vida cotidiana, y en los movimientos sociales revolucionarios, el sueño de una sociedad donde no haya lugar para la explotación del trabajo y los trabajadores. Pero ya lo sabemos: después de la Segunda Guerra Mundial comienzan a producirse transformaciones en el sistema capitalista que, al cabo de poco más de tres décadas, harán que la opciones sociales y artísticas utópicas pierdan las condiciones históricas de su posibilidad, en beneficio de otras: las que harán posible el imperio del capital y de la mercancía, ahora "globalizados". El imperio de nuestros días "posmodernos".

Obviamente, el lector de las novelas de Couve reconoce siempre en sus personajes unas construcciones literarias manifiestamente modernas. Sin embargo, el tiempo de sus historias, tan esencial para comprenderlos, no es exactamente el tiempo lineal de la modernidad. Algo singular lo vuelve

\footnotetext{
También es pertinente señalar que junto al tiempo lineal dominante subsisten asimismo "otros tiempos", como lo destaca el estudio de Sigfried Kracauer, Historia. Las últimas cosas antes de las últimas.

En Chile, Baldomero Lillo ofrece una imagen desoladora de los mineros del carbón en su inolvidable libro de cuentos Sub-terra (1904).
} 
anómalo: es un tiempo moderno, pero de alguna manera mutilado. Lo mutilado salta a la vista: es un tiempo a cuya estructura le falta el futuro, y el futuro siempre ha sido el supuesto de la linealidad del tiempo. Esta falta de futuro es, en mi lectura de Couve, lo que justamente alegoriza la "falta de cabeza" del pintor Camondo.

Ahora, ¿qué mundo específico es el de Couve? Todos los diversos planos que pueden distinguirse en sus narraciones, espacios o escenarios de las acciones, identidad de los personajes, vestimentas, "atmósferas" y hasta modos del lenguaje, cargan consigo connotaciones de época. ¿De qué época? Las connotaciones apuntan en una dirección inequívoca: reconocemos en el de Couve el mundo de la belle époque, de la alta y la baja burguesía en su versión chilena, capitalina y provinciana, de las últimas décadas del siglo XIX y las primeras del XX. Un mundo que sin saberlo vive en el tiempo de su fin. Desde la perspectiva de un saber de la historia de la sociedad moderna es, obviamente, un lugar común el acontecimiento al que yo mismo me refería antes: que la belle époque concluye, en Europa y derivadamente en todas partes, con la Primera Guerra Mundial. Por eso mismo la decisión de Couve de incorporarla a sus relatos tiene un sentido evidente a la luz de nuestra hipótesis de lectura: hace de la "belle époque" una metáfora del tiempo sin futuro de su propio mundo: del tiempo descabezado.

Me parece que una construcción crítica como ésta, junto con permitirnos asignarle un significado coherente a la alegoría del pintor convertido en estatua de cera y al final descabezado, hace posible al mismo tiempo una lectura retroactiva omnicomprensiva de la producción narrativa de Couve, desde Alamiro. Dicho al revés es igualmente cierto: desde el comienzo, las novelas de Couve van reiterando un modo de ser en el tiempo que encuentra en las dos últimas, La comedia del arte y Cuando pienso en mi falta de cabeza, la alegorización de su sentido como el habitar un tiempo descabezado, sin futuro. Así es el mundo de los personajes de Couve: una eterna reiteración de sí mismo. Más exactamente: una eterna repetición de sí mismo como ruina del pasado. El pasado no es más que su presente. O también: un movimiento sin movimiento. Es justamente éste el significado, apenas cifrado en una metáfora, de lo que nos dice el narrador cuando Marieta descubre a Camondo convertido en estatua de cera: "Además, ¿volverse una copia inanimada, fría y perfecta no había sido el constante empeño de Camondo durante toda su vida?" (p. 152). Lo dice el narrador, que lo sabe, pero el lector siente que lo dice como si tradujera una imagen del inconsciente de la misma Marieta. 
Un mundo como "copia” reiterada de sí mismo. ¿Una "compulsión a la repetición"? (Freud) ${ }^{4}$.

Hay una operación crítica pendiente en mi análisis, de importancia no menor. La siguiente: si la figura del descabezado es la alegoría de un tiempo sin futuro, no puede dejar de ser también, y simultáneamente, la alegoría de la particular identidad con que se nos presenta la forma interior que la narrativa de Couve va dejando a la vista en su desarrollo. Cada una de estas formas debería ser tema de otros ensayos que me gustaría escribir. Por ahora me limito a dar cuenta sumaria de algunas de ellas. Dejo sí formulado el imperativo de "verdad" literaria al que responden: todas ellas hacen suyo el tiempo descabezado.

Una de estas formas, que compromete de manera episódica a varias de sus novelas, se encuentra ejemplarmente en Una lección de pintura (Couve 1979): la forma genérica del cuento de hadas. En ella las acciones, los personajes y sus identidades se nos aparecen como recortados en un tiempo "otro", uno donde el narrador no se siente obligado a dar "razón" de lo que cuenta, o, si la da, responde a otra lógica. No debe engañarnos pues el marco "realista" de esta novela, con escenarios de ciudades o pueblos existentes en Chile. En efecto, si bien el narrador sitúa a sus personajes en el "barrio Morandé", un lugar próximo a la ciudad de Llay Llay, los personajes y sus acciones no son "realistas". Una característica de los cuentos de hadas es la indeterminación del tiempo y del espacio. En Una lección de pintura esta indeterminación es la regla. Un día cualquiera, que recuerda el "érase una vez" de los cuentos de hadas, una madre vestida de luto con su hijo recién nacido en brazos llega al barrio Morandé, a una casa "que no colindaba con nada ni con nadie" (p. 11 y s.). Nunca se supo de quién era ni "cómo había conseguido esa casa que por tanto tiempo estuvo desocupada" (p. 13). El propio narrador le informa al lector que la madre y su hijo han ingresado a un espacio de transfiguración: "Así como las almas escogidas al atravesar la puerta del paraíso se transforman en seres traslúcidos y alados, del mismo modo Elvira Medrano, al cruzar de 
luto frente a la veintena de casas y boliches de Morandé con un crío en los brazos, se volvió de madre soltera en viuda respetable, y los vecinos sintieron en sus corazones, no el repudio a que obliga lo primero, sino la compasión que despierta lo segundo" (p. 13).

Una vez instalados en su casa, se suceden las indeterminaciones y los indicios de que nos encontramos en un mundo donde lo imposible ocurre. De pronto descubrimos que ese niño al parecer recién nacido o de pocos meses, queda solo en la casa. Mientras ella sale a hacer trámites, lo deja en el interior de un "barril". Imposible no asociar de inmediato el barril con el motivo de "el héroe en el tonel", estudiado por Propp en los cuentos maravillosos, y con el sentido general de tránsito o "pasaje" (Propp 357-360)5. En el barril, el niño juega con un marinero de trapo o duerme. Sin decirnos cuánto tiempo había pasado, "Una noche (...), al inclinarse para rescatarlo, advirtió que el niño no estaba; tampoco el muñeco" (p. 14). ¿Dónde estaban? En la cocina, "parloteando alegremente"... Y "a medida que el tiempo transcurrió" (no sabemos cuánto), ya el niño ayudaba a su madre "realizando pequeñas tareas como barrer, lavar la loza, ordenar la ropa" (p. 14 y s.). La culminación de esta asombrosa serie de indeterminación se produce "el día" en que el niño, "envuelto en un chal", sale de su casa, cruza la calle principal de Morandé "tirando resuelto un cochecito con el marinero dentro" (p. 15). Solo a la luz de la lógica del tiempo indeterminado de los cuentos de hadas es posible reducir el asombro del lector a la complicidad de una aceptación de estos pequeños sucesos.

La novela es inagotable en su disponibilidad para ofrecer nuevas sorpresas del mismo orden. Solo quiero llamar la atención sobre una más, sin duda la de mayor visibilidad, la más llamativa de todas porque gira en torno al personaje central del relato, el niño, de nombre Augusto. Se nos aparece un día, provocando expectación en la tertulia de Aguiar, el farmacéutico que reúne en su casa, donde también trabaja la madre de Agusto, a un grupo de amigos interesados en oír y compartir las noticias culturales y las charlas sobre pintura impresionista de Aguiar. Rápidamente el farmacéutico toma al niño bajo su alero, dispuesto a poner a su alcance lo que debe aprender. Augusto se concentra y aprende rápidamente. Aguiar comienza a interesarse por lo que nadie le ha enseñado al niño y sin embargo hace perfectamente: sus

Vladimir Propp, Las raíces históricas del cuento. Ver el apartado sobre "El héroe en el tonel", pp. 357-360. 
dibujos. Dibuja una carretela y ante la incredulidad de Aguiar, le dice que él también puede copiar el cuadro de un alquimista colgado del muro. Acepta incrédulo el desafío y le proporciona una caja de acuarela. El niño, después de terminar su copia, se va. Aguiar da vueltas, demorando el momento de ver la hoja dejada sobre el mesón. Finalmente se acerca y mira: “¡Dios mío, este niño es un genio!", dice (p. 38 y s.). Viaja con él a Santiago, a visitar el museo. Más tarde, luego de que Augusto le hiciera un retrato perfecto solo con betún de zapato y pasta de dientes, tomó la decisión mayor: llamó a Viña del Mar a una profesora de pintura conocida para que aceptara en su curso al joven, y luego a unos primos que vivían allá para que acogieran al alumno. La "lección de pintura" dejó desconcertada a la profesora. Augusto hacía todo bien, perfecto, pero no como resultado de un proceso de aprendizaje, sino porque él ya sabía hacerlo. Está claro entonces: Augusto no es un personaje "realista". Es un personaje del mundo de los cuentos de hadas donde las identidades de cada uno están dadas de una vez para siempre, sin "historia": se es bruja, hada protectora, o un pintor genial.

También en la novela El pasaje (Couve 203) se cruzan constantemente los límites de lo verosímil realista, tanto en los objetos como en los espacios de vida y en la identidad de los personajes. Rogelio, un niño asimismo de edad indeterminada, pero presumible un preadolescente, vive con su madre en una casa junto a otras dentro de un mismo pasaje. Una casa gastada por el uso, más bien vulgar, con la excepción de un pequeño patio de luz interior, junto a la escalera, que recibía una luz tamizada por los vidrios empavonados del techo, dotada de una condición tal que le daba a los objetos que ahí se encontraban (pan, macetas, loza, tiestos) "un peso, una calidad y una presencia casi sagrada". Esa iluminación "regida desde lo alto" rescataba de la pobreza circundante al mismo Rogelio dotándolo con "la apariencia de un ángel”' (p. 229).

No solo el espacio: personajes y objetos repiten el mundo de los cuentos de hadas. A la casa de Rogelio estuvo viniendo por algunos meses una joven tísica a bordar un gran mantel de su madre. Para él, la joven, Sofía, era "hermosa" y la acompañaba mientras tejía. Un día ella le trajo un regalo en una vieja caja de madera barnizada. Ella misma la abrió: "En el fondo, agazapado, un pequeño conejo plegaba sus orejas contra el lomo. Era blanco y temblaba” (p. 230). Rogelio lo sacó y lo llevó al patio de luz, es decir, a un 
espacio de la misma naturaleza del regalo: maravilloso. Sofía, el hada buena, se fue "como una sombra". Otra joven, Melania, "sólo un año mayor que él" (¿qué edad tenían?), llegó a vivir con su familia a una casa del mismo pasaje. Entre Melania y Rogelio surge algo así como una atracción mutua, un idilio sin palabras. También Melania llega un día con un "obsequio, envuelto en delicado papel de seda blanco, atado por una hebra de plata". Después de decirle "Toma", se va. Rogelio, sorprendido y ansioso, lo abre, "examinando alborozado entre sus manos un hermoso alfiler de corbata que tenía, sobre una barra dorada, un pequeño revólver de nácar” (p. 242). No hace falta convencer a nadie para abrirse a la certeza de que ese conejo y este alfiler no son objetos de este mundo, pero sí del fabuloso de las hadas 7 . Oblicuamente, el regalo, por su refinamiento, evoca la "belle époque", vivida desde el espacio de una pequeña burguesía pobre.

Para dar con el camino que conduce a la segunda forma presente en la configuración del mundo narrativo de Couve, resulta revelador en este sentido descubrir la frecuencia con que en distintas novelas se nos aparecen los espejos, sobre todo en las dos últimas. El espejo en que nos miramos nos devuelve nuestra imagen como la de un otro. Cuando es el niño el que por primera vez se mira, y ve otro que es él mismo, estamos frente a la "estadio del espejo" (Lacan, 11-18), cargada de narcisismo, punto de partida del complejo proceso de la construcción del yo, del sujeto como diferenciación. Pero la construcción del sujeto también puede fracasar, y la imagen en el espejo puede llegar a ser entonces el símbolo de una fijación temprana en la fase del llamado "narcisismo primario" (Freud, p. 235). Es de esa fijación que resulta la forma del doble: el otro es yo, yo soy el otro. Una forma descrita por el psicoanálisis ${ }^{8}$, presente asimismo en cuentos de la tradición oral.

$7 \quad$ Además del libro de Propp ya citado, he tenido en cuenta, al escribir este apartado sobre el cuento de hadas, algunos libros: Bruno Bettelheim, Psicoanálisis de los cuentos de hadas, Jack Zipes, El irresistible cuento de hadas, Sarah Hirschman, Gente y cuento. ¿A quién pertenece la literatura?

$8 \quad$ Sobre todo, Otto Rank, El doble. También sobre el doble, el ensayo de Freud "Lo ominoso". En Obras completas. Vol. XVII, pp. 234-238. En este ensayo hay un comentario de Freud que puede aplicarse perfectamente a Couve. A los significados del doble cabe también 
La forma del doble es común en la narrativa de Couve. Desde luego, la estatua de cera no solo es la estatua del pintor Camondo: es su doble. Por eso aquí, más que en ningún otro lugar son tan reveladoras las palabras del narrador de La comedia del arte, dichas después de que Marieta le sacara la cabeza a la estatua. Palabras ya citadas pero que ahora adquieren un nuevo significado: "Además, ¿volverse una copia inanimada, fría y perfecta no había sido el constante empeño de Camondo durante su vida?". Una vida, pues, empeñada en ser obstinadamente una "copia" de sí mismo, es decir, ser su propio doble.

De las novelas de Couve donde la forma del doble es perceptible, El picadero $^{9}$ es la que lo introduce y desarrolla de manera más sistemática. Los dobles y desdoblamientos hacen un tejido de personajes y sucesos que cubren toda la narración. Es necesario distinguir en esta novela los desdoblamientos de los dobles. Los primeros ocurren por contigüidad: un mismo personaje se vive como uno dividido en dos. Así ocurre con el señor Sousa, que se mueve entre una vida disoluta y otra sometida a las normas de su clase social: "la doble vida del señor Sousa llegó a dividirlo en dos partes iguales (...). Esta situación de equilibrio entre el mundo que se atrevía a exhibir y aquel otro clandestino, hizo creer al señor Sousa que lo poseía todo. Pero como sucede en ese juego en que dos partes tiran de una cuerda para atraerse a la otra, el señor Sousa no pudo, llegado el momento, armonizarlos" (p. 99). Otro caso es el de las dos hermanas, Raquel y Diana, cada una un reflejo invertido de la otra, una portadora de lo que la otra no es: "Las aventuras de Raquel necesitaban de la resonancia que en Blanca alcanzaban, y ésta sentía una secreta alegría de saberse la estabilidad que su hermana no era capaz de lograr. En realidad, Blanca vivía de los acontecimientos de Raquel, y ésta tenía su seguridad en el zurcido cotidiano de su hermana" (p. 82).

Los personajes de esta novela, sus vestimentas, el ambiente en que se mueven y la arquitectura de las casas que habitan evocan claramente el mundo de la "belle époque" y el lujo de una burguesía enriquecida. El relato comienza en un picadero donde un joven, cuyo relato leemos en primera

incorporar "todas las posibilidades incumplidas de plasmación del destino, a que la fantasía sigue aferrada, y todas las aspiraciones del yo que no pudieron realizarse a consecuencia de unas circunstancias externas desfavorables, así como todas las decisiones voluntarias sofocadas que han producido la ilusión del libre albedrío" (p. 236).

Esta novela forma parte de El cuarteto de la infancia, pero aquí la citaré por Narrativa completa. 
persona, hace impecablemente sus ejercicios de equitación, vigilado y aplaudido por su padre. De pronto, informada por el padre de las proeza del hijo, hace su aparición en el picadero una dama, de luto, hermosa y bien montada. Es Blanca Diana de Sousa. Ella lo invita a visitarla y a que le enseñe el arte de la equitación. Pronto la relación va atrapándolos a ambos en una secreta complicidad erótica. Un día en que el joven entra sorpresivamente al dormitorio de Diana, la descubre en camisón. Se arroja junto a ella en la cama e inicia un acercamiento cada vez más sensual que se entremezcla con los recuerdos de la madre: “¡No sigas, Angelino!” ¿Angelino se llama el joven equitador? Angelino es el nombre del hijo de Diana, también equitador, muerto no hacía mucho arrastrado por su caballo en una arriesgada demostración de pericia. ¿A quién se dirige Diana? ¿A su hijo, para que no continúe con esa peligrosa demostración? ¿Al joven equitador que en su cama junto a ella también intenta una maniobra peligrosa? A ambos. Estamos aquí frente a la figura del "doble". El joven equitador es el doble de Angelino, o éste es el doble de aquél. Y Diana, al seguir el juego erótico con él, se pone al borde de un incesto sublimado. El episodio de la cama termina con una advertencia de Diana: "¡Yo te hago daño, esto no puede continuar!", y con una reflexión reveladora del joven narrador: "Si mis labios hicieron justicia a tanto desvelo e imprimieron en los suyos un beso, fue sólo en sueños. Sueño dentro de otro sueño, hijo dentro de otro ajeno, viejo amor dentro de uno nuevo" (p. 63).

De nuevo estamos ante un tiempo que se vuelve sobre sí mismo: el pasado se repite en el presente, el presente de un pasado, en un movimiento de circularidad donde los personajes viven sus vida como vidas encapsuladas, sin una verdadera apertura. La única apertura que conocen, y que al final confirma el encierro, es la del yo que se desdobla en mitades contrapuestas que mantienen entre sí una relación de implicación recíproca, o la del yo que es él y al mismo tiempo otro, el doble de otro.

Hay una tercera forma, en otro plano de las narraciones, visible como el lugar donde transcurren las historias de personajes fundamentales de Couve: un lugar ficticio, aun cuando aparezca investido de una identidad aparentemente real. Es el caso de Cartagena, un balneario del litoral central de Chile, espacio urbano escenario de vida de muchos personajes en varias novelas de este narrador, entre ellas las dos novelas últimas. Aquí, por razones temáticas (las 
de mi ensayo), pondré el foco en La comedia del arte. Tal como en Llay Llay de La lección de pintura, el realismo del nombre, igual que el de Cartagena, ubicados sin problemas en el mapa de Chile, es desmentido rápidamente por la índole del mundo narrativo que se despliega en ellos o desde ellos. Un mundo éste cuyo tiempo cotidiano es imposible traducir, sin mediación crítica, desde la lógica o el código del tiempo cotidiano del lector.

Estos lugares ficticios son bien conocidos en la narrativa hispanoamericana. Antes y después de William Faulkner (1897-1962), el novelista estadounidense que introdujo el imaginario Condado de Yoknapatawphak y su capital, Jefferson. En otro ensayo me referí a estos espacios llamándolos "macrofiguras narrativas" 10 . El primero fue Misiones, creado por Horacio Quiroga en su libro de cuentos Los desterrados (1926). Le siguieron Santa María, una ciudad ficticia a la que remiten algunas novelas de Juan Carlos Onetti ( $L a$ vida breve, 1956, El astillero, 1962, Juntacadáveres, 1964). Luego el pueblo fantasma llamado Comala, de la novela Pedro Páramo (1955) de Juan Rulfo. Por cierto, el más conocido de esta clase de lugares es Macondo, de la novela Cien años de soledad (1967) de Gabriel García Márquez. El más conocido, pero no el último. A la serie hay que agregar Santa Teresa de la novela 2666 de Roberto Bolaño, publicación póstuma (2004). Si bien ficticia, el lector no puede dejar de asociar Santa Teresa con Ciudad Juárez, de México, y su referente implícito, famosa por ser escenario emblemático de los crímenes atroces, sobre todo contra mujeres, perpetrados por los narcotraficantes.

Cartagena se suma pues a esta tradición, de una manera sin duda particular. Una de las constantes que la distingue es el ser una ciudad detenida en el tiempo, o mejor, una ciudad cuyo tiempo cotidiano, el que viven los personajes principales, es un tiempo a todas luces terminal: presente como ruina del pasado. Fácil de observar en La comedia del arte. Los habitantes de la pensión San Julián, observábamos antes, son en este sentido una metáfora de este tiempo terminal: mujeres viejas, las dueñas y las pensionistas, que habitan ese lugar como el último de sus vidas. Cuando mueren las dueñas, los patrones llegan a rescatar a sus viejas sirvientas para llevarlas a otro lugar de término. La San Julián, confirmando su condición de metáfora, no volverá a ser habitada, y quedará entregada ya a una existencia que hace

10 Nota de la Revista Chilena de Literatura: con el fin de salvaguardar el anonimato de este trabajo, hemos omitido provisionalmente información que refería explícitamente al/ a la autor/a del mismo. 
visible su propia fantasmagoría. Solo recibirá la visita escondida de la musa disfrazada de mujer barbuda, acompañada del pintor Camondo, llevado allí por la musa para ser convertido en estatua de cera, y la de Marieta, que se llevará la cabeza del pintor.

La San Julián, lugar de vidas terminales. Camondo descabezado en ella, es decir, tiempo descabezado: terminal. Metáfora sobre metáfora: la San Julián, Camondo descabezado son también metáforas de un mundo social y cultural sin continuidad ( $\sin$ futuro), cerrado sobre sí mismo: el de la "belle époque" (de la alta y la baja burguesía). El juego con ese momento de la historia moderna tiene en la narrativa de Couve una base histórica local que él explota desde una gran intuición literaria, artística, para levantar su propio mundo. En efecto, Cartagena fue, desde las últimas décadas del siglo XIX hasta las primeras del XX, el balneario belle époque de la burguesía chilena, que viajaba a Europa y regresaba con modelos y materiales para construir y decorar sus casas, para vestirse y exhibir el lujo, la riqueza. La Cartagena de Couve, la del presente de sus relatos, no es ya más que su propio recuerdo, el de un tiempo pasado devenido en puro vestigio.

Las metáforas del tiempo terminal no se agotan con el descabezado y la San Julián. A éstas debemos sumar pues las playas de Cartagena, la Chica y la Grande. No son solo los lugares que hacen de Cartagena un balneario. En La comedia del arte parecen haberse convertido en espacios de representaciones rituales. Ya habíamos hablado de cómo el pintor Camondo elige la playa para montar su "abjuración" ritualizada y paródica. También la playa es una superficie de borde, orilla donde el movimiento del mar se detiene y sobre la cual arroja cuerpos y desechos. Si el movimiento del mar es el movimiento del tiempo, entonces la playa metaforiza el lugar donde el hombre vive su presente como tiempo terminal. Es decir, el hombre es aquel que ha quedado "varado" en la playa del tiempo, en su presente. Hay una figura en la que podemos leer una representación patética de este significado metafórico. La de una mujer loca que recorre la playa mirando al mar y esperando empecinada que el mar le devuelva a su pareja, víctima de un naufragio. Su locura parece consistir en que no sabe que su espera es vana y que ella misma es otro náufrago. $\mathrm{O}$ mejor: ella misma es el náufrago que somos.

La ciudad de Cartagena imaginada por Couve es el espacio donde toma cuerpo y se vuelve más visible la naturaleza de su mundo narrativo como un mundo de tiempo descabezado, terminal. Y aquí es necesario dar cuenta de otro juego de espejos, uno entre ficción y realidad, entre tiempo narrativo y tiempo biográfico. En 1986 se fue a vivir a Cartagena. A la luz de sus novelas, 
especialmente las dos últimas, y de cómo murió, puede uno conjeturar que no solo se fue a vivir a Cartagena sino que asumió su historia como si fuera propia. Y de una manera total y radical: allí, en su casa de Cartagena, se suicidó en 1998. Su suicidio: ¿metáfora póstuma de un tiempo terminal, "descabezado"?

En 1996, a dos años de su muerte, Couve reunión cuatro de sus novelas y las publicó bajo el título de El cuarteto de la infancia. Las narraciones incluidas aquí, en muchos aspectos, son de gran importancia para definir el arte de Couve. Pero ahora nos interesa solo el prólogo de la compilación. Es del mismo autor y contiene lo que podría llamarse su "proyecto" de escritura narrativa. Según Couve, su proyecto tiene modelos, nombres que lo encarna. No duda en identificar su proyecto como "realista" y en situarlo en el tiempo como heredero de la "escuela" realista europea, francesa en verdad, del siglo XIX. Cita los nombres de Stendhal, Balzac, Flaubert y otros. No profundiza en las razones de su adhesión, en los principios que podrían estar en juego. Pero sí informa de la génesis de su admiración por los prosistas franceses: sus ancestros franceses. Un gesto difuso además de esnob. Lo que nos importa en todo caso es la filiación que él confiesa y la verdad de la misma.

¿Es "realista" el arte narrativo de Couve? Y si lo es, ¿sobre qué bases lo sería, sobre qué principios? Una manera de abordar estas preguntas, la que aquí adoptaré, consiste en partir de lo que los estudios sobre el realismo francés del XIX han definido como sus principios, junto con las diferencias perceptibles en la obra de sus protagonistas, para luego examinar en qué medida la narrativa de Couve podría insertarse en ese paisaje de principios y diferencias. Esos principios y diferencias los derivaré del libro clásico de Erich Auerbach, Mimesis: La realidad en la literatura ${ }^{11}$, y de las páginas que le dedica al análisis de la producción novelesca de Stendhal, Balzac y Flaubert, para Auerbach los "fundadores del realismo moderno" o "contemporáneo".

En diferentes pasajes de su ensayo Auerbach insiste en que las novelas de Stendhal, Balzac y Flaubert se abren a la realidad social de su momento, a la

11 Erich Auerbach, Mimesis: La realidad en la literatura. México, Fondo de Cultura Económica, 1950. 
vida cotidiana de familias burguesas de clase media o baja, e intentan por esta vía dar cuenta de un presente "histórico". Balzac "concibe el presente como historia, o sea, el presente como algo que ocurre surgiendo de la historia" (p. 452). Los tres comparten lo que Auerbach considera "los dos signos característicos del realismo moderno": 1. "se toman muy en serio episodios reales y corrientes de una clase inferior, de la pequeña burguesía de provincia". 2. "los episodios corrientes son engarzados exacta y profundamente en una determinada época histórico-contemporánea” (p. 457).

La "realidad" cotidiana como materia de las narraciones de estos escritores franceses es pues estrictamente "histórica", corresponde a un momento, el presente, dentro de la historia de una sociedad moderna. ¿Se repite este principio en Couve? Tajantemente, no. Sí, sus personajes, de clases medias, bajas o altas, parecieran exhibir las marcas de una cotidianeidad, o en todo caso atisbos, pero en cualquier caso no es la cotidianeidad de un presente "histórico", que viene de una "historia" cuyo movimiento, o proceso, lo trascenderá. El presente en Couve no puede ser sino fantasmagórico: es el presente de una historia detenida en el tiempo. O también: es el presente de su propia historia, o es una historia que coincide con su presente. Es verdad, a veces, tal como en Balzac, el personaje y su espacio de vida (por ejemplo, su habitación, sus relaciones de amistad o familiares) mantienen entre sí una relación de mutua confirmación: son el espejo uno del otro. Simetría que podemos ver en la novela El pasaje (la señora Carter, Perla Muro) o en $L a$ lección de pintura (los dos hermanos a cuya casa es enviado Augusto por su protector). Pero en Couve esta correspondencia no crea ningún presente histórico, ningún momento de continuidad o tránsito del tiempo: es una imagen en estado de flotación, de suspensión temporal. La metáfora de la belle époque evocada en algunas narraciones (El picadero, una de ellas) vendría solo a confirmar la discontinuidad temporal, el presente entregado a sí mismo.

Sí hay cierta consonancia, cierta afinidad entre Couve y Flaubert, no desde luego en sus narrativas como un todo, sino en determinados puntos. Siguiendo también el análisis de Auerbach, son aquí especialmente pertinentes algunas observaciones suyas. En una de ellas afirma que con Flaubert "el realismo se hace imparcial, impersonal y objetivo" (p. 452). Destaca en él tanto su absoluta confianza "en la veracidad del lenguaje" (p. 457) como su voluntad de "obligar al lenguaje a entregarle la verdad sobre los objetos que caen bajo su observación" (p. 462). Una tarea cuyo cumplimiento solo tendrá lugar imitando "los procedimientos de la Creación" (p. 458). En su prólogo a El cuarteto de la infancia, Couve formula una poética similar. Siempre, dice, 
tuvo una meta: "alcanzar una prosa depurada, convincente, clara, distante, impersonal (...), castigar el contenido y el lenguaje, intentar ese engranaje que da como resultado, más que un libro, un verdadero objeto" (p. 8). En sus entrevistas solía repetir esta misma idea. En cuanto a la imitación de los procedimientos de la Creación, es ejemplar en este sentido un gesto del personaje central de su dos últimas novelas, Camondo, pintor de caballete. En La comedia del arte lo vemos de regreso de una sesión de pintura con una tela donde pintaba el mar. Miró el mar y miró su pintura y arrojó al viento esta última como si así declarara su fracaso en la imitación de los procedimientos de la Creación. Ya vimos a dónde lo conducirá posteriormente cuando "abjure" de sus talentos ante el dios Apolo.

Pero hay todavía otro lazo con el novelista francés. En la obra de Flaubert, señala Auerbach, "se pone de manifiesto algo así como una amenaza oculta: es una época en la que su sombría falta de perspectivas parece cargarla de materia explosiva" (p. 462). Aun cuando la obra de Couve carezca de manera inmediata de un anclaje "histórico", cosa que sí tiene la de Flaubert, comparte con la de éste esa "amenaza oculta". En efecto, el mundo de las novelas de Couve, asentado en un tiempo indeterminado, sin futuro, abierto a lo irreal y fantástico, también carga consigo una soterrada "amenaza": una pulsión de muerte, una latencia de catástrofe, una inminencia trágica ${ }^{12}$.

El presente del lector no puede ser nunca ajeno a la seducción que un gran escritor ejerce en él. En el caso de Couve y el interés renovado del lector actual en sus novelas, ¿qué componente de nuestro presente podría de alguna manera estar interviniendo en esa adhesión? Más directamente: ¿qué relación de complicidad habría entre el mundo narrativo de Couve y el mundo de su lector, el nuestro, nuestro mundo "posmoderno"? O también: ¿qué relación entre ese mundo de Couve y la sensibilidad nuestra? No estoy hablando desde luego de simetrías, de imposibles paralelismos. Lo que hay son ciertas

12 Lo mismo podría afirmarse de la pintura de Couve. Véase el libro de Claudia Campaña, Adolfo Couve: una lección de pintura. Santiago, Ediciones Metales Pesados, 2015, pp. 17-102. 
correspondencias, ciertas afinidades, ciertos juegos en espejo, signos que operan como zonas de tránsito.

Un primer punto de encuentro pasa por imágenes recurrentes en la narrativa de Couve pero que también forman parte de la identidad de lo moderno, es decir, del capitalismo y su cultura. Me refiero a las imágenes que instalan el espectáculo de la ruina. De algunas de ellas ya habíamos hablado: la pensión San Julián y sus viejas, de los primos de Aguiar que reciben al joven pintor Augusto (La lección de pintura), los ambientes venidos a menos de El pasaje, el propio Camondo y su modelo Marieta en el ocaso de sus vidas y oficios. No es posible reducir el sentido de la ruina aquí a procesos "naturales", propios de las cosas y del hombre. Dijimos: los personajes de Couve, sin saberlo, viven el presente de un tiempo cotidiano como ruina del pasado. Completemos ahora ese juicio. En realidad, lo que Couve hace no es sino proyectar sobre los personajes y sus ambientes una condición constitutiva del capitalismo y su funcionamiento histórico. El capitalismo vino para producir mercancías (materiales, culturales) y la mercancía no puede renovar su oferta al consumo sino dando "de baja" a la anterior y entregándola al horizonte de su ruina.

Así lo vio tempranamente Benjamin en sus "Tesis de filosofía de la historia" ${ }^{13}$. En la tesis N ${ }^{\circ}$ 9, reflexiona sobre un cuadro de Paul Klee, Angelus Novus. Es el "ángel de la historia" que "ha vuelto el rostro hacia el pasado" y lo que ha visto se traduce en la expresión de pasmo de su rostro y en la rigidez de sus alas. ¿Qué ha visto? "Donde a nosotros se manifiesta una cadena de datos, él ve una catástrofe única que amontona incansablemente ruina sobre ruina, arrojándolas a sus pies". Quisiera "detenerse, despertar a los muertos y recomponer lo despedazado", pero se lo impide un huracán que "le empuja irreteniblemente hacia el futuro, al cual da la espalda, mientras que los montones de ruinas crecen ante él hasta el cielo. Ese huracán es lo que nosotros llamamos progreso" (Benjamin 183). Sin embargo, en el pensamiento de Benjamin había todavía un lugar para el futuro, una esperanza mesiánica en la "redención" de los sometidos. En Couve, ese lugar ya no existe: sus personajes viven pues simplemente en un presente como ruina del pasado, en un tiempo descabezado.

El nuestro, nuestro tiempo cotidiano de la era del consumo posmoderno, gira sobre sí mismo, es decir, sobre su ruina. Esperamos que el mañana confirme el presente, que nos reponga como consumidores de mercancías 
y como testigo de su ruina. Más de lo mismo. Nuestra vida cotidiana, igual que la de los personajes de Couve, está habitada por signos que nos hablan de ella misma como un punto terminal, de resolución y cumplimiento de un orden, de un sistema. Signos que hacen posible imaginar un futuro incierto y a ratos apocalíptico, un horizonte poblado de clones y drones, o un horizonte de desastre climático o ecológico. Están por todas partes y son leídos desde distintos órdenes disciplinarios: antropología, sociología, filosofía, historia del arte y de la literatura. En este sentido hay nombres de pensadores contemporáneos que se nos han vuelto familiares: Deleuze, Baudrillard, Agamben, Vattimo, Bauman, Virilio, Augé, etc. El sistema capitalista no puede dejar de responder a su esencia: está diseñado solo para producir y seguir produciendo nuevas mercancías, es decir, acumulando ruinas, destruyendo sin parar la naturaleza, haciendo del hombre cada vez más un no humano. En síntesis: un mundo así, un tiempo cotidiano así, no puede sino sintonizar con el tiempo "descabezado" de Couve.

\section{BIBLIOGRAFÍA}

Erich Auerbach. Mimesis. La realidad en la literatura. México: Fondo de Cultura Económica, 1950.

Benjamin, Walter. "Tesis de filosofía de la historia”. En Ensayos escogidos. Traducción de H. A. Murena. Buenos Aires: Editorial Sur, 1967.

Bettelheim, Bruno. Psicoanálisis de los cuentos de hadas. Trad. Silvia Furió. Buenos Aires: Editorial Paidós, 2012.

Campaña, Claudia. Adolfo Couve: una lección de pintura. Santiago, Ediciones Metales Pesados, 2015.

Couve, Adolfo. La comedia del arte. Santiago: Editorial Planeta Chilena, 1995Cuarteto de la infancia. Buenos Aires: Editorial Seix Barral, 1996. "Prólogo al Cuarteto de la infancia (citado por Couve, Obras completas. Santiago: Tajamar Editores, 2013). Narrativa completa. Santiago: Editorial Planeta Chilena, 2003.

Freud, Sigmund. "Lo ominoso". Obras completas. Vol. XVII. Buenos Aires: Amarrortu Editores, 2009.

Hirschman, Sara. Gente y cuento. ¿A quién pertenece la literatura? Trad. Julio Paredes. Buenos Aires: Fondo de Cultura Económica, 2011.

Kracauer, Siegfried. Historia. Las últimas cosas antes de las últimas. Trad. Guadalupe Marando y Agustín D’Ambrosio. Buenos Aires: Las Cuarenta, 2010. 
Lacan, Jacques. "El estadio del espejo como formador de la función del yo ("je")". Escritos. Trad. de Tomás Segovia. México: Siglo XXI Editores, 1971.

Morales T. Leonidas. Figuras literarias, rupturas culturales. Santiago: Pehuén Editores, 1993. Conversaciones con Diamela Eltit. Santiago, Editorial Cuarto Propio, 1998.

Propp, Vladimir. Las raíces históricas del cuento. 1974. Trad. José Martín Arincibia. Madrid: Ediciones Fundamentos, 2008.

Rank, Otto. El doble. Traducción de Floreal Mazía. Buenos Aires: Ediciones Orión, 1976.

Ricoeur, Paul. La memoria, la historia, el olvido. 2004. Trad. Agustín Neira. Buenos Aires: Fondo de Cultura Económica, 2010.

Stendhal. Rojo y negro. Trad. Antonio Vilanova. Bogotá: Pinguin Random House, 2015.

Weber, Max. La ética protestante y el espíritu del capitalismo. Trad. Luis Legaz. Barcelona: Ediciones Península, 1994 (13ª ed.).

Zipes, Jack. El irresistible cuento de hadas. Trad. Silvia Villegas. Buenos Aires: Fondo de Cultura Económica, 2014. 